\title{
VI \\ A NOTE ON THE SIGNIFICANCE OF URINARY THREADS
}

\author{
By, W. E. ORCHARD, M.B., Ch.B., D.P.H., \\ Assistant Venereal Diseases Officer to the City of Salford
}

IT has been stated that the urinary filaments are of two kinds, (I) those that sink in the test glass, and (2) those that float. Fraser ${ }^{1}$ describes five types, but for practical purposes there are only two.

An investigation into the value which can be ascribed to the microscopical examination of these threads was undertaken at the Salford Municipal Clinic. The cases were the ordinary routine cases of gonorrhœea, at all stages of the disease.

In the actual examination, the urine: was allowed to stand in the test glass for five minutes to allow the heavy threads to sink. The threads were mounted and stained by Pelouze's modification of Gram's method. The slide should first be cleaned with xylol, and the thread is teased out and fixed by drying in the air. The cells are by this means preserved intact, and are examined with the I/I2 oil-immersion lens and a $\mathrm{X}_{5}$ objective.

It has been said that threads which sink are composed of pus cells and/or other cells and organisms, while floating threads are composed mainly, if not entirely, of epithelial cells, and mucus. An attempt was made to verify this, and to discover whether the examination of such threads gave any indication of the stage of healing of the condition.

It is often assumed that floating threads are of no consequence, the assumption being that they are due to some degree of exfoliation of the mucous membrane, or of over-treatment ; and that sunken threads are evidence of a continued infective process. Lees ${ }^{2}$ states that in an infection of the glands of Littre, the urine contains pus threads or threads of muco-pus. It will be evident, however, that the number and heaviness of the filaments are no indication of the extent of infection or of the stage of healing. It will be seen that gonococci are found in 


\section{SIGNIFICANCE OF URINARY THREADS}

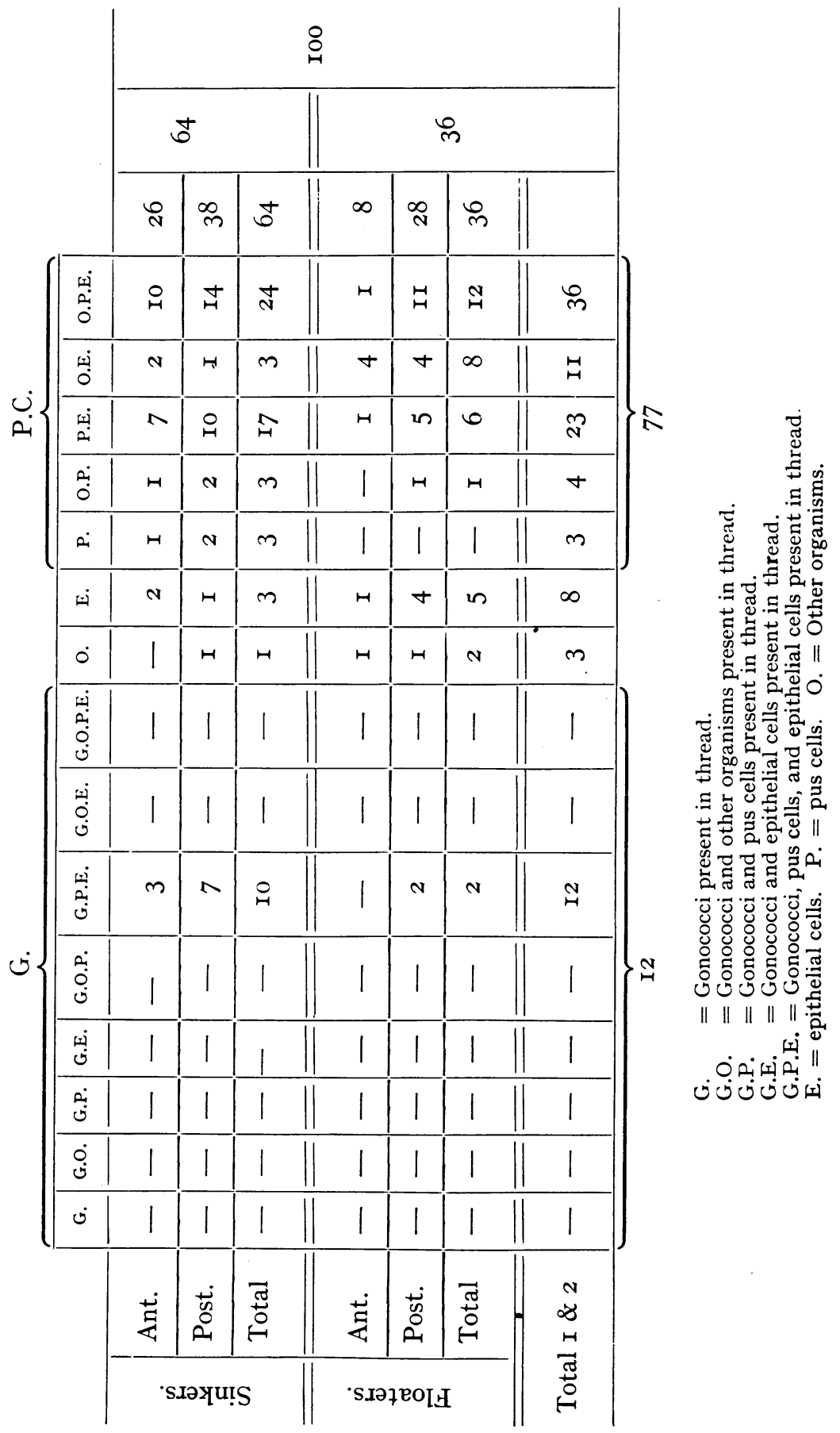




\section{BRITISH JOURNAL OF VENEREAL DISEASES}

5 per cent. of cases taken at all stages of the disease, including those cases that show resistance to treatment and are being seen at a late stage. In 6 per cent. of sinking threads at all stages of the disease, no pus cells whatever could be seen. While this is not a large percentage, it shows that it is impossible to say merely by examining the filaments in the test glass whether they will contain pus cells or gonococci or neither. Pus cells were present in 75 per cent. of floating threads.

Luys ${ }^{3}$ makes the observation that the greater number of pus-containing threads are from cases of posterior urethritis. One was unable to confirm this. A number of cases were examined by the three-glass test, and it was found that no special cell characteristic could be ascribed to the threads, whether they came from the anterior or posterior urethra; where threads were present in the first washing, they were of the same nature as those passed in the urine from the posterior urethra and bladder.

It was seen in 8 cases that organisms of meatal origin can be suspended in mucus and assume the characteristics of either floating or sinking threads. Particles that float owing to entanglement in mucus may contain pus cells and should not be disregarded.

At the beginning of this investigation the length of time the patient was under treatment was considered, but as every patient varies in the intensity of his treatment as well as in his reacting and resisting powers, this aspect was not gone into further. All cases were treated by the same routine methods.

In certain cases of urethritis where no discharge can be expressed, the examination of a filament is of value in giving an idea of the condition of the mucous membrane. Thus in one case, the patient having completed part of his treatment apparently successfully, and having been free from discharge almost from the first day, a thread was taken from an otherwise clear and perfectly normal urine, and found to contain gonococci. It is better for this purpose to examine a sunken thread than one which is suspended, although either, if they are the only types present, give the true picture.

\section{Summary}

(I) An investigation was made into the cellular constituents of urinary filaments, roo cases were 


\section{SIGNIFICANCE OF URINARY THREADS}

examined and it was found: in 64 cases of sinking threads $(a)$ I5.6 per cent. contained gonococci and pus cells, and (b) 73.4 per cent. contained pus cells only. In 36 cases of floating threads $(a) 5.5$ per cent. contained gonococci and pus cells, and $(b) 75.2$ per cent. contained pus cells only.

(2) No definite diagnostic value could be ascribed to the threads on the mere fact of their sinking or otherwise.

(3) The presence of threads is an indication that the urethra is not normal and is evidence of continued infection.

(4) A method of ascertaining the condition of the mucous membrane where no discharge can be expressed, by the examination of the threads is suggested.

I wish to thank Colonel Burke for his permission to carry out this investigation, and for his valuable help. I also thank Messrs. Ireland and Blackburn of the Clinic Staff for their assistance, ably and cheerfully given.

\section{REFERENCES}

(I) Fraser, A. Reith : “A Monograph on Gonorrhœa," p. 84. Kimpton, I923.

(2) LEEs, DAvid : " Diagnosis and Treatment of Venereal Diseases," p. 386. Livingstone, I93I.

(3) Luys, G. : "Gonorrhœa and its Complications," p. 88. Baillière, Tindall \& Cox, I922. 